\title{
USE BORDA ANALYSIS TO DETERMINE THE PRIORITY OF THE INDONESIAN NAVAL TECHNOLOGY COLLEGE DEVELOPMENT STRATEGY
}

\author{
Ayip Rivai Prabowo, Zaenal Fanani, Moeljadi, Tjahjanulin Domai \\ Brawijaya University, Malang, East Java, 65145, Indonesia
}

\begin{abstract}
The Indonesia Naval Technology College requires an organizational development strategy in order to produce professional student outcomes and master maritime technology. Based on this, we can choose the priority of development strategies by weighting based on expert choices. The problem in this research is how to determine the priority of strategies that can be implemented in the development of the Indonesian Naval Technology College. The purpose of this research is to weight some strategies in developing the Indonesian Naval Technology College. In this study, the SWOT analyst and Borda Analysis methods are used to determine the assessment of the strategy. The results of the study indicate that to be able to improve the professionalism of soldiers in the fields of science and technology, it is necessary to increase the quantity and quality of complete laboratory infrastructure facilities, publication of lecturer and student research in national and international journals, Changes in the structure of the ideal Indonesian Naval Technology college will be able to support operational education and development of new study programs and the regulation of curriculum changes in each study programs that leads to the field of science and technology in the rank of marine.
\end{abstract}

Keywords: The Indonesian Naval Technology College, SWOT Analysis, Borda Analysis, Development Strategy.

\section{INTRODUCTION}

In the field of development and development of human resources, the Navy has several platforms, namely, Kodiklatal, AAL, Seskoal and STTAL. The Indonesia Naval Technology College (STTAL) as a forum that has two roles at once, namely the development of the potential of Human Resources and the development of technology in meeting the needs of the Navy. STTAL as the executor of the task of Mabesal has the responsibility in organizing science and technology education programs for soldiers of the Indonesian National Army / Police in order to establish, maintain and develop the science and technology capabilities of the Indonesian National Armed Forces / Police to answer the challenges of advancing defense equipment and in order to realize the independence of defense equipment in the environment Indonesian National Army / Police.

At this time the development of technology and information systems are based on 4.0 so that the defense system owned by the Navy must have the good combat capability, facilitate its crew, possess extraordinary destructive power, have high accuracy and speed of movement. The soldier's professionalism, ability in manning the cysts is a demand that must be met. The main needs of the Navy today are professional soldiers who have capabilities in the field of marine science and technology and have academic and professional qualifications that are certified by the National Professional Certification Board (BNSP). Soldier professionalism that must be fulfilled in the field of marine science and technology includes warship technology, bases, aircraft, amphibious vehicles, maritime safety, intelligence, cyber, medical and operations research analysis. In its implementation through the Tridharma of higher education, namely education, research and community service.

STTAL as a university must reach National standards by optimizing its various resources. The fulfillment of laboratory facilities in each study program will improve the abilities and expertise of lecturers and students in research. Human resources, especially certified lecturers and laboratory staff will be able to support all research activities and teaching and learning process. Through laboratory-based education will be able to increase research publications for lecturers and students in accredited national and international journals so that they get recognition for Intellectual Property Rights. With the existence of science and technology-based curriculum regulations in each Departments it is expected to be able to support the duties of the Navy. The development of study programs with educational components based on basic scientific patterns in the field of maritime affairs which includes the addition of D-3, S-1, S-2 and S-3 study programs will increase soldier professionalism.

With the large demands and responsibilities of STTAL to become a center for the development of defense science and technology in the field of military, maritime and reliable maritime affairs at the regional level in realizing the independence of the main weapons system (defense equipment), STTAL continues to strive to improve capabilities, as well as the quality of human resources which is in response to these demands. With the increase in capability 
and quality of existing human resources, it will increase the workload in STTAL.

This study also refers to previous studies such as research with titles Comparative Analysis of Simple Additive Weighting Method and Weighted Product Method to New Employee Recruitment Decision Support System (DSS) at PT. Warta Media Nusantara (Setyawan, Arini, \& Akhlis, 2017), Comparison of rank-based weighting methods for multi-criteria decision making (Sureeyatanapas, 2016), Comparison of Multi-Criteria Decision Support Methods (AHP, TOPSIS, SAW \& PROMENTHEE) for Employee Placement (Widianta, 2018), Dematel As A Weighting Method In Multi-Criteria Decision Analysis (Kobryń, 2017), Multi Attribute Decision Making Using Simple Additive Weighting and Weighted Product in Investment (Melia, 2016), Stochastic multi-criteria decision-making: an overview to methods and applications (Celik, Gul, \& Yucesan, 2019).

This research is divided into four phases, phase 1 introduction, step 2 material and methodology, step 3 results and discussion and final stage are conclusions and suggestions.

\section{MATERIALS AND METHODS}

\subsection{Theory of Human Resource Development.}

Human resources have a vital role for an organization in making goals, strategies, innovations to achieve goals (Ahammed \& Taslim, 2017). For this reason, organizations need quality human resources with professional competence obtained through good education, training and organizational development programs (Liu, 2017). STTAL as an educational institution of the Navy has the task of increasing the professionalism of soldiers through education and training in order to have competence in supporting the tasks of the Navy.

The Indonesian Navy as the main element of the defense force at sea, is required to play an active role in maintaining and maintaining the sovereignty of the Republic of Indonesia. In carrying out its duties and functions, the fostering of Navy personnel is directed to improve the quality of human resources, so as to have the attitude and behavior in providing the best service (excellent service) and high performance for the glory of the nation and the state. In carrying out national defense, it is based on the strength and capability of human resources, namely the Indonesian people, both military and non-military, which is supported by a reliable weapons and defense management system. Therefore the need for quality human resources is a strength asset for national defense.

According to the Regulation of the Minister of Defense of the Republic of Indonesia Number Per / 23 / M / XII / 2007, that qualified human resources for national defense are defined in three main areas, namely responsiveness, responsiveness and trengginas. Responsive human resources, namely human resources who have high intellect, expertise, abilities, science and technology and professionalism. Resonant Human Resources is having a strong and tough mentality. Trengginas human resources are human resources who have a healthy and strong body / physical condition. Armed Navy personnel who are responsive, responsive, and trengginas can only be obtained from programmed and continuous education and training.

\subsection{Theory of Professionalism.}

Quality human resources have professional skills, discipline and high moral integrity (Evans \& Linda, 2008). Professional soldiers are soldiers who are trained, well-educated, well equipped, do not practice politics, do not do business and are guaranteed welfare, and follow state political policies that adhere to the principles of democracy, civil supremacy and human rights, the provisions of national law and ratified international law. So a professional soldier must have mastery of knowledge in depth, able to convert knowledge into skills and always uphold the ethics and integrity of the profession.

One way to increase professionalism is through a modern and professional education system so that soldiers have the ability to learn and respond to the forms of national security challenges and threats that are the responsibility of the Indonesian National Army. On the other hand, professionalism is a capability, discipline in carrying out tasks, always oriented towards achieving results and having high integrity contained in three aspects, namely expertise, social responsibility and cooperation. Therefore a person's professionalism is measured by the level of expertise in carrying out the profession, having social responsibility in carrying out the profession and being able to work with fellow people with other professions.

The requirements that must be met in developing professionalism are: (1). Recognition, namely the need for recognition from professional institutions that are officially both nationally and internationally. (2) Organization, which is a place for someone to develop the abilities and skills of a professional. (3) Criteria, namely in carrying out the roles, obligations and professional abilities required in accordance with the criteria of professional standards as well as national and international qualifications. (4) Creative, which has the ability to develop bright, innovative and creative ideas for the betterment of the organization. (5) Drafter, namely the ability to create and create work concepts both strategies, implementation, coordination, communication and evaluation both short and long term.

\subsection{Strategic Management Theory}

Strategic management can be defined as the art and science of formulating, implementing, and evaluating cross-functional decisions that enable organizations to achieve their goals (Ozleblebici \& Cetin, 2015). This definition implies, strategic management focuses on integrating management, 
marketing, finance / accounting, production / operations, research and development, and information systems to achieve organizational success. The term strategic management in this text is used synonymously with the term strategic planning. The latter term is more often used in the business world, while the former is often used in academia. The goal of strategic management is to exploit and create new and different opportunities for tomorrow; Long-term planning, by contrast, tries to optimize tomorrow's trends for today. The strategic plan results from difficult managerial choices among many good alternatives, and it signifies a commitment to certain markets, policies, procedures, and operations in lieu of other action programs.

Strategic management has now evolved to the point where its main value is in helping organizations operate successfully in dynamic and complex environments. To be competitive in a dynamic environment, companies become less bureaucratic and more flexible. In a stable environment like in the past, competitive strategy only involves defining a competitive position and then maintaining it.

\subsection{SWOT analysis}

SWOT analysis is an analysis that emphasizes 4 aspects, namely Strength, Weakness, Opportunity, and Threat (Ommani, 2011). This SWOT analysis will identify internal and external factors of the Bravo Naval base development strategy so that potentials can be developed in the future and can overcome existing weaknesses. From the internal side, it can be seen the strengths or weaknesses that are owned for the development of Bravo Naval base, while from the external side there will be seen opportunities and threats from the outside, after identifying these factors the formulation of the strategy is done using the SWOT method.

\subsection{Borda Analysis}

The Borda Method proposed by its inventor Jean Charles de Borda in the 18th century, is one of the methods used to determine the best alternative of the selected alternatives. Each alternative decision maker will be judged by its weight based on its ranking. The biggest weight is the best alternative for decision makers. The basic idea of the Borda Method is to give weight to each of the first ranking criteria, second rank, and so on. The Borda Method is one method that can be used to accommodate the ranking of decision makers who use weights at each ranking position generated by decision makers (Korhonen, Moskowitz, \& Wallenius, 1992).

\subsection{Research Methodology}

To solve problems in the observed research, steps are needed and determined to describe the approach and model of the problem. The steps taken are:

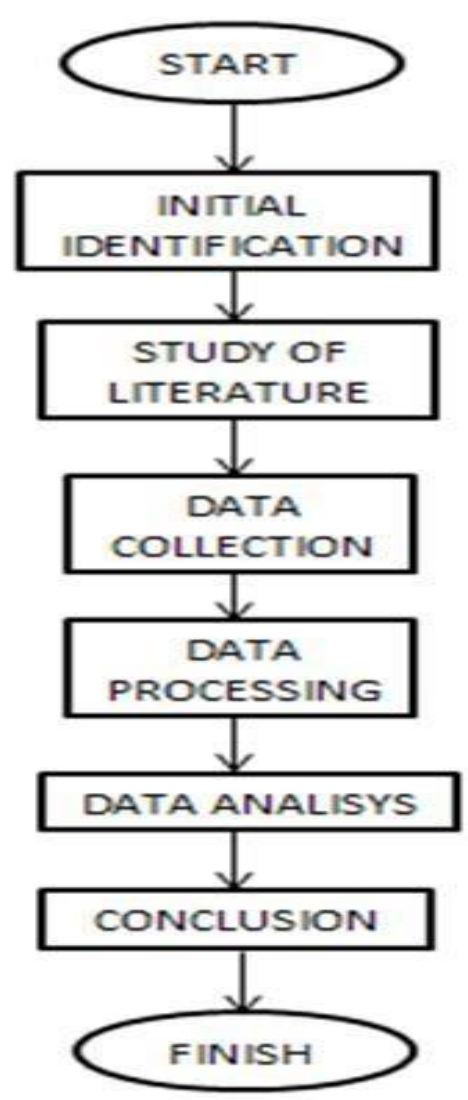

Figure 1. Research Methodology Flowchart 
The steps taken are (1) Initial Identification of the element of The Indonesian Naval Technology College, (2) Study Literature, (3) Data Collection, (4) Data Processing, (5) Data Analysis, and (6) Interpretative of Conclusion.

The target of this research is to determine the priority strategies that can be implemented in the development of Indonesia naval Tecolog College. The step of this research is Step 1 to identify problems by looking at internal and external factors, Step 2 conducting the analysis, Step 3 weighting and analyzing, and Step 4 giving suggestions for improvement and conclusions.

\section{RESULT AND DISCUSSION 3.1. SWOT Analysis}

Referring to the goals and objectives of evaluating and implementing the SWOT analysis, it will be known what are the strengths and weaknesses and strategies for developing The Indonesian Naval Technology Colleges and the opportunities that support the development of Naval technology Colleges and threats that will be faced in the development.

1. Strength. The definition of Strength in a SWOT analysis is the strength or strength that exists in a company or organization that affects the strategic decision making process.The Strength found in the development of the Naval technology Colleges is the increasing state budget for defense, marine-oriented government policies.

2. Weakness. The definition of Weakness in a SWOT analysis is a weakness that exists in a company or organization that influences strategic decision making processes. Weakness that is found in the development of Naval Technology Colleges is the absence of an independent internal accreditation institution, lack of library support facilities and research institutions and community services that are not yet in accordance with university standards.

3. Opportunities. The definition of opportunity in a SWOT analysis is the opportunity that exists in a company or organization that influence strategic decision making processes, which is an opportunity found in the development of Naval Technology Colleges is the cost of research assistance from the government, the existence of research institutions that utilize universities as research implements military.

4. Threats. The definition of Threat in a SWOT analysis is the threat that exists in a company or organization that influences the strategic decision making process that poses a threat to the development of Naval Technology Colleges is the existence of universities that open defense study programs, limited research costs.

Table 1: SWOT strategy approach matrix

\begin{tabular}{|c|c|c|}
\hline$x$ & $\mathbf{S}$ & $\mathbf{W}$ \\
\hline & Strategy S-O & Strategy W-O \\
\hline $\mathbf{O}$ & $\begin{array}{l}\text { 1. improve the quality of human } \\
\text { resources in the field of research. } \\
\text { 2. making applied military research }\end{array}$ & $\begin{array}{l}\text { 1. carry out routine internal checks } \\
\text { 2. repairing library facilities by } \\
\text { cooperating with government } \\
\text { institutions } \\
\text { 3. make research and community } \\
\text { service standards in accordance } \\
\text { with university standards. }\end{array}$ \\
\hline & Strategy S-T & Strategy W-T \\
\hline $\mathbf{T}$ & $\begin{array}{l}\text { 1. strengthening academic and research } \\
\text { fields } \\
\text { 2. cooperating with government } \\
\text { institutions for marine research }\end{array}$ & $\begin{array}{l}\text { 1. strengthen the quality of internal } \\
\text { education } \\
\text { 2. In collaboration with government } \\
\text { institutions in an effort to strengthen } \\
\text { the research field. }\end{array}$ \\
\hline
\end{tabular}

From the table above, The SWOT strategy approach consists of 4 categories, consisting of strategy I (Strength-Opportunity), strategy II (Weakness-Opportunity), strategy III (StrengthThreat), strategy IV (Weakness-Threat). Strategy I has 2 strategies. Strategy II there are 2 strategies. Strategy III has 3 strategies. Strategy IV has 2 strategies. The strategies mentioned above are grouped or sorted from Strength-Opportunity in numbers 1 to 2, Weakness-Opportunity in numbers 3 to 5 , Strength-Threat numbers 6 to 7 , Weakness-
Threats numbers 8 to 9 , according to table 3.3 symbols and strategies.

\subsection{Borda Analysis to find out the priority criteria.}

Based on the SWOT analysis above, 9 development strategies for The Indonesian Naval Technology College have been determined. Then weighting is done to give the priority order of the strategy chosen to be carried out by The Indonesian Naval Technology College. These criteria are: 
Table 2: Criteria of Strategy

\begin{tabular}{|c|c|l|}
\hline No & Code & \multicolumn{1}{|c|}{ Criteria } \\
\hline 1 & $\mathrm{~K} 1$ & Improve the quality of human resources in the field of research \\
\hline 2 & $\mathrm{~K} 2$ & Making applied military research \\
\hline 3 & $\mathrm{~K} 3$ & Carry out routine internal checks \\
\hline 4 & $\mathrm{~K} 4$ & Repairing library facilities by cooperating with gvernment institutions \\
\hline 5 & $\mathrm{~K} 5$ & Make research and community service standards in accordance with university standards \\
\hline 6 & $\mathrm{~K} 6$ & Strengthening academic and research field \\
\hline 7 & $\mathrm{~K} 7$ & Cooperating with government institutions for marine research \\
\hline 8 & $\mathrm{~K} 8$ & Strengthening the quality of internal education \\
\hline 9 & $\mathrm{~K} 9$ & n collaboration with government institutions in an effort to strengthen the research field \\
\hline
\end{tabular}

Table 3: Expert Choice in Criteria

\begin{tabular}{|c|c|c|c|c|c|}
\hline & & \multicolumn{4}{|c|}{ EXPERT CHOICE RANK } \\
\hline No & Code & expert 1 & expert 2 & expert 3 & expert 4 \\
\hline 1 & K1 & 2 & 3 & 1 & 2 \\
\hline 2 & K2 & 3 & 4 & 3 & 4 \\
\hline 3 & K3 & 4 & 1 & 5 & 6 \\
\hline 4 & K4 & 5 & 2 & 7 & 8 \\
\hline 5 & K5 & 1 & 5 & 9 & 1 \\
\hline 6 & K6 & 6 & 6 & 2 & 3 \\
\hline 7 & K7 & 7 & 9 & 4 & 5 \\
\hline 8 & K8 & 8 & 8 & 6 & 7 \\
\hline 9 & K9 & 9 & 7 & 8 & 9 \\
\hline
\end{tabular}

\begin{tabular}{|c|c|c|}
\hline & RANK & WEIGHT \\
\hline $\mathrm{K} 1$ & 22 & 0.14379085 \\
\hline $\mathrm{K} 2$ & 22 & 0.14379085 \\
\hline $\mathrm{K} 3$ & 22 & 0.14379085 \\
\hline $\mathrm{K} 4$ & 22 & 0.14379085 \\
\hline $\mathrm{K} 5$ & 17 & 0.111111111 \\
\hline $\mathrm{K} 6$ & 13 & 0.08496732 \\
\hline $\mathrm{K} 7$ & 22 & 0.14379085 \\
\hline $\mathrm{K} 8$ & 7 & 0.045751634 \\
\hline $\mathrm{K} 9$ & 6 & 0.039215686 \\
\hline
\end{tabular}

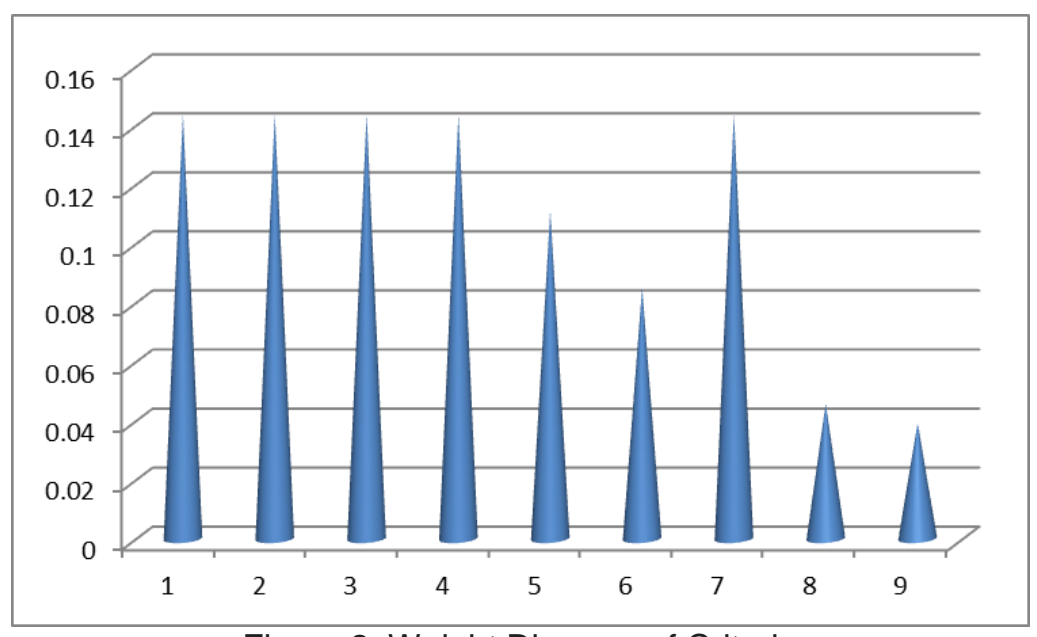

Figure 2: Weight Diagram of Criteria

Based on the results of weight processing based on the data above, the criteria 1 , criterion 2 , criterion 3 , criterion 4 and criterion 7 are the first priority strategies that can be taken in the development of The Indonesian Naval Technology College with a criterion weight of 0.143 . Whereas the second priority is criterion 5 with a criterion weight of 0.111 and third priority is criterion 8 with a criterion weight of 0.046 and lastly is criterion 9 with a criterion weight of 0.039 . From these results it is very apparent that SO and WO strategies are prioritized in the framework of developing The Indonesian Naval Technology College.

To overcome this problem, several strategies can be carried out, including: 1). Improve the quality of human resources in the field of research through 
training on research according to existing regulations. 2). Making applied military research. 3). Carry out internal check routine. 4). Repairing library facilities by cooperating with government institutions by implementing collective agreements. 5). Make research and community service standards in accordance with university standards. 6). Academic and research, strengthening field. 7). Cooperating with government institutions for marine research. 8). Strengthening the quality of internal education. 9). Collaboration with government institutions in an effort to strengthen the research field.

\section{CONCLUSION}

Based on the results of the discussion, the conclusion of this research is that in the framework of developing The Indonesian Naval Technology College, the priority strategies that can be implemented are: 1). Improve the quality of human resources in the field of research with a value of 0.143. 2). Making applied military research with a value of 0.143 . 3). Carry out internal check routine with a value of 0.143 . 4). Repairing library facilities by cooperating with government institutions with a value of 0.143 . 5). Cooperating with government institutions for marine research with a value of 0.143 . $6)$. Make research and community service standards in accordance with university standards with a weight value of 0.111 .7$)$. Academic and research, strengthening field with a value of 0.084 . 8). Strengthening the quality of internal education with a weight value of 0.045 . 9). Collaboration with government institutions in an effort to strengthen the research field with a value of 0.039 .

\section{Acknowledgment}

The authors greatly acknowledge the support from Brawijaya University for providing necessary resources to carry out this research work. The authors are also grateful to the anonymous reviewers and journal editorial board for their many insightful comments, which have significantly improved this article.

\section{REFERENCES}

Ahammed, \& Taslim. (2017). Personnel Management to Human Resources Management9HRM): How HRM Functions? Journal of Modern Accounting and Auditing, 113.

Celik, E., Gul, M., \& Yucesan, M. (2019). Stochastic multi-criteria decision-making: an overview to methods and applications. Journal of Basic and Applied Sciences, 1-9.

Evans, \& Linda. (2008). Professionalism, Professionality and the Development of Education Professional. British Journal of Educational Studies, 20-38.

Kobryń, A. (2017). Dematel As A Weighting Method In Multi-Criteria Decision Analysis. Multiple Criteria Decision Making Journal, 154-167.

Korhonen, P., Moskowitz, H., \& Wallenius, J. (1992). Multiple criteria decision support-A review. European Journal of Operational Research, 361-375, 361-375.

Liu, Y. (2017). Review of Human Resource Management Function of Front Line Manager. OJBM Journal, 671-679.

Melia, Y. (2016). Multi Attribute Decision Making Using Simple Additive Weighting and Weighted Product in Investment. International Academic Journal of Business Management, 1-15.

Ommani, A. R. (2011). Strengths, weaknesses, opportunities and threats (SWOT) analysis for farming system businesses management: Case of wheat farmers of Shadervan District, Shoushtar Township, Iran . African Journal of Business Management Vol. 5(22), pp. 94489454, 30 September, 2011, 9448-9454.

Ozleblebici, Z., \& Cetin, S. (2015). The Role of Managerial Perception within Strategic Management: An Exploratory Overview of the Literature. Social and Behavioral Sciences, 296-305.

Setyawan, A., Arini, F. Y., \& Akhlis, I. (2017). Comparative Analysis of Simple Additive Weighting Method and Weighted Product Method to New Employee Recruitment Decision Support System (DSS) at PT. Warta Media Nusantara. Scientific Journal of Informatics, 34-42.

Sureeyatanapas, P. (2016). Comparison of rankbased weighting methods for multi-criteria decision making. KKU Engineering Journal, 376-379.

Widianta. (2018). Comparison of Multi-Criteria Decision Support Methods (AHP, TOPSIS, SAW \& PROMENTHEE) for Employee Placement . Journal of Physics: Conference Series, 1-5. 